\title{
Arab Spring Revolutions throughout Modern Arabic Poetry ${ }^{1}$
}

\author{
Khaled Igbaria \\ Kaye Academic College for Education \\ Israel \\ Email: khalid3025 [AT] gmail.com
}

\begin{abstract}
One of the core dominant events, in the Middle East in 21th century, was Arab Spring revolutions in 2010-2011. These revolutions aimed to achieve democracy and get rid of the dictator regimes in the Arab countries. No doubt that Arab Spring had political social and economic reasonable and significant impacts. This paper will examine various reflections on the Arab revolutions of the Arab Spring (2010-2011) through modern Arab poetry, focusing on four selected poems as cases of study. In addition to the aimed historical reading, this paper attempts to analyse the selected poems focusing literary and poetic methods, as well as language and diction, comparing between them. For diversity, while all the selected poems are modern Arabic poetry, one of the selected poems is the neo-classic Arabic poetry of Ibrāhīm Obaydī, and the three others are free verse poetry from Ahmed Matar, Mus 'ab al-Mūrādī, and Ahmad Msä dih. Methodologically, this study is analytic, comparative and inductive, relying relevant poems of the selected four poets. This paper suggests not only that the Arab Spring played a significant historical role in the Middle East, leading to intensive civil and non-civil armed conflicts, but also, Modern Arab poetry contributes to historical documenting immortalizing the Arab Spring revolutions including their aims and motivations, as well as their social political and cultural impacts.
\end{abstract}

Keywords--- Modern Arab poetry, Arab Spring (2010-2011), history and poetry

\section{INTRODUCTION}

To explain the background of this study, this opening aims to explore a brief discussion on the relationship between language and history in general, and Arabic and history in particular. Then, to describe the core event in Arab countries in the first decade of the $21^{\text {st }}$ century - the 'Arab Spring' or Arab 2010-2011 revolutions-including the aims of these revolutions in full, as well as their failures in short.

Language is not only an instrument or a symbol, but it also represents a nation's spirit (Harel-Shalev, 2016; Cook, 2000). Arabic literature, since classical times, is a mirror for Arab societies and their lives, including politics, economics, cultures, and civilizations. In this context, Shamsuddin and $\mathrm{Hj}$. Ahmad (2017) explore how languages construct such a mirror:

All languages in the world have a particular importance, because the language is a tool of expression and imagination of human feelings and emotions. So, the languages are such a mirror for the life of nations and people. In this mirror, we can see the pictures full flipped to their culture, civilization, geographical regions, development, customs and traditions: their happiness and sorrows, societies and economy, living natural sources and factors of death. (p. 123)

In harmony with that, Simon (2015) indicates that, while Arabic poetry in the $19^{\text {th }}$ and $20^{\text {th }}$ centuries focused on nationalism and the collapse of the Ottoman Empire, in the $21^{\text {st }}$ century, it explores both nationalism and political themes. Thus, one could expect that fiction and literature could reasonably represent historical social and political events. In this context of the relationship between history and literature as well as poetry, Schirmann assures us that,

Even if we do not intend merely to amass general facts and numbers, it is precisely the smallest details that are incomparably important: a line is joined with a line, and from the totality emerges a living and colorful picture of the deed as it was. (Tanenbaum, 2002, p. 386)

Further, Einbinder considerably highlights the historical role of the literary text, indicating that deep reading and attention to subtle literary detail can elicit information that is not otherwise readily available (Tanenbaum, 2002).

In the first decade of the $21^{\text {st }}$ century, in the Middle East a core dominant historical event happened, which is the 2010-2011 'Arab Spring' revolutions. Lanchovichina (2018) describes the mentioned revolutions, confirming their significance and impact: "The Arab Spring protests caught most of the world by surprise and precipitated a chain of events that changed the course of history in the Middle East and North Africa (MENA)" (p. 24).

${ }^{1}$ The translations of the poems analyzed are mine. 
The term 'Arab Spring' encompasses three types of revolution in Arab countries: one type was successful and non-violent, such as the Egyptian revolution; the second was successful but violent, such as the Libyan revolution; and the third was a failed type of violent revolution, such as in Bahrain, Syria, and Yemen (Singh, 2012). Sequentially, Arab Spring revolutions began in Tunisia, in December 2010, as a result of Tunisian police brutality against Mohammed Bouazizi, who was a grocery vendor in Sidi Bouazid city; Bouazizi committed suicide by setting fire to himself on 17 December 2010 to protest the Tunisian police brutality. Consequently, thousands of people hit the streets in Sidi Bouazid to protest Tunisian police brutality and to demand better living conditions. The demonstrations and protests quickly became larger and led to the death of dozens of individuals in Tunisia. Then, when Tunisian President Zine el-Abidinde Ben Ali saw that the situation was out of control, he stepped down and escaped to Saudi Arabia (Ghanem, 2016; Henry \& Ji-Hyang, 2013; Makdisi, 2017; Singh, 2012; Tete and Dash).

The escape of Ben Ali was considered a moral victory for the Tunisian protesters in terms of both the power and the size of their demonstrations. This moral victory encouraged the Egyptians, in January 2011, to hit the streets to demand removal of President Hosni Mubarak. That is to say, Ben Ali's escape had a contagious effect in Arab countries like Egypt, Syria, Yemen, and Jordan (Tete and Dash). When Mubarak also stepped down on 11 February 2011, this was another moral victory for the mass protests held in Tahrir Square in Cairo, which encouraged Arab people in other Arab countries to hold demonstrations and mass protests in Libya, Yemen, and Syria. In this context, Makdisi (2017) says, 'The unexpected success of mass, street mobilization in both Tunisia and Egypt acted as a spark for similar mass movements in other Arab countries' (p. 29).

On 15 March, pro-democracy protests began in Syria, then on 22 May pro-democracy demonstrations began in Morocco; from there, actions occurred in August in Libya, and in September in Yemen. On 20 October 2011, Libyan dictator Colonel Muammar Gaddafi was captured by rebels, tortured, and killed. On 23 October 2011, Tunisia held its first democratic parliamentary elections. On 23 November 2011, Yemeni dictator Ali Abdullah Saleh signed a powersharing agreement. He resigned altogether in February 2012 and was later killed, in 2017, while the country was still engulfed in a civil war. On 28 November 2011, Egypt held its first democratic parliamentary elections. In June 2012, Mohamed Morsi was elected president, but he was removed from power by a military coup in July 2013, and he has remained in prison to this day. That is to say, the Egyptian revolution was neither non-violent nor successful, but a failed, violent revolution. As for the Libyan revolution, it too was a failed, violent revolution because it did not achieve its aims as well as it led to a continuous civil war in Libya. However, these revolutions have had significant implications, including armed conflict, which are beyond the agenda of this research (Ewenstien, 2012; Lanchovichina, 2018). In this context, the term 'Arab Spring' has received some criticism, but I use it because of its familiarity to readers. I will return to discuss the failure of the Arab Spring, but first it is worth exploring the reasons why people were pushed to engage in mass protests and demonstrations as well as the aims and goals of the Arab revolutions.

Singh (2012) significantly explores the general factors:

Several common factors were behind the protests such as dictatorship or absolute monarchy, human rights violations, corruption, economic decline, unemployment, extreme poverty, increasing food prices and a number of demographic reforms may have been a contributing factor in all of the protests. (p. 204)

Undoubtedly, the core factor was the dictatorship regimes in these Arab countries. Because such dictatorships led to corruption, the absence of human rights, poverty, a lack of economic growth, and other malign effects. It is no accident that the most prominent shouts of demonstrators throughout the Arab revolutions was that 'people want to overthrow the regime'. Arab citizens realized that dictatorial regimes were the core obstruction that prevented social and economic justice, and that they caused absolute monarchy, deep poverty, and corruption. Interestingly, Igbaria (2018) explore the same critical concept, but within the context of Lebanese feminist woman novelist Laylá Ba'albakī's short stories in the 1950s1960s. He confirms:

The short stories criticize the non-democratic rulers in Arab countries of the mid-1950s to 1963, and especially those Arab countries, which derive their wealth from petrol exports. The implicit criticism is that they have not shared the wealth fairly between their citizens, but rather that all the money has gone to the rulers and their families. By indicating this, the stories criticize the fundamental relationship between wealth and political power, in Arab countries (Ba'albakī, 2009, pp. 118-119). (p. 14)

This confirms and historically memorializes that the Arab people and nations have suffered from dictatorial regimes and rulers for several decades. Moreover, Arab novelists and writers such as Ba'albakī documented critiques of the absence of democracy and socio-economic justice. Note that this fictional contribution and debate is not within this study's scope.

However, thus, recently Arab Spring revolutions attempted to remove decades of dictatorial regimes from Arab countries such as Tunisia, Egypt, Libya, Syria, and Yemen and to bring instead freedom and democracy. In this context, Acemoğlu, Naidu, Robinson, and others (May, 19, 2014) state that

When we disentangle what components of democracy matter the most for growth, we find that civil liberties are what seem to be the most important. We also find positive effects of democracy on economic reforms, private investment, the size and capacity of government, and a reduction in social conflict. 
In other words, democracy leads to civil liberties, economic reforms, and private investment, which means that democracy considerably increases economic growth. Moreover, Doucouliagos and Ulubasoglu explain in detail the hypothesis that 'democracy leads to economic growth':

Supporters of the "democracy promotes growth" hypothesis argue that the motivations of citizens work and invest, the effective allocation of resources in the marketplace, and profit-maximizing private activity can all be maintained in a climate of liberty, free-flowing information, and secured control of property (North, 1990). Democracies can limit state intervention in the economy; are responsive to the public's demands on areas such as education, justice and health, and encourage stable long-run growth (Baum and Lake, 2003; Lake and Baum, 2001; Rodrik, 1998). (p 61)

However, despite the academic debate regarding the relationship between democracy and economic growth, which again is beyond this study's agenda, I argue for the mass Arab protesters in saying that democracy is much better than dictatorship because democracy leads to social justice, greater employment, more equitable distribution of money and other resources, and freedom. In this context, Hafez Ghanem (2016) argues that economic issues were a key cause leading to the Arab revolutions:

Economic issues were at the heart of the Arab Spring. It is true that Arab economies had solid growth rates during the decades preceding the uprisings. However, that growth was not inclusive. The middle class was squeezed, youth were left out, women were pushed out of the labor market, and any regions (for example, Upper Egypt and Western Tunisia) were marginalized. Limited economic opportunities and increasing inequality were key drivers of the Arab Spring. (p. 39)

On the other hand, Singh (2012) argues that Arab revolutions occurred because people sought human rights in the context of dictatorships in Arab countries. Thus, we could conclude that Arab revolutions were caused by several main factors: dictatorial regimes, corruption, lack of economic growth, unemployment, social and economic injustice, and absence of human rights and freedom. These issues broadly encompassed many fields such as education, politics, gender, feminism, media, and economics. describes:

Arab revolutions clearly failed in general to achieve their aims and agendas, a failure that Ghanem (2016)

Today, most people try to avoid using the term "Arab Spring." Very little has been achieved in the area of democratic reforms. Instead of building vibrant and stable democracies, most of the countries of the Arab Spring revolutions have entered a phase of violence and instability. Political turmoil has been associated with macroeconomic instability, low growth, and high unemployment. The revolutionaries' dreams for more freedom and dignity, and more bread and social justice, appear now even less attainable than before the uprisings. (p. 7)

When Ghanem (2016) concludes that 'little has been achieved', he does acknowledge those achievements that did occur: Tunisia achieved considerable progress toward democracy, Morocco experienced significant democratic reforms, and Morocco and Jordan reached more political and economic stability. For Ghanem (2016), the Arab Spring is not a season but a long road for new political, social, and economic order in Arab countries. However, explanations for the failure of the Arab Spring and the detailed implications of this failure, even though they can be mentioned within the discussion, are beyond our agenda here.

To conclude, this study will focus several reflections on the Arab revolutions of the Arab Spring (2010-2011) within modern Arab poetry, dealing with four selected poems as /cases of study. Furthermore, this article will investigate comparingly literary styles and poetic devices, throughout the studied poems of the poet Ibrāhīm Obaydī, and other three free verse poems from Ahmed Matar, Mus 'ab al-Mūrādī, and Ahmad Msā' dih.

\section{MODERN ARABIC POETRY DOCUMENTS ARAB SPRING REVOLUTIONS}

The Arab revolutions of the 2010-2011 Arab Spring sought to change corrupt dictatorial Arab regimes. This was manifest through not only the slogan raised by the revolutionaries, 'people want to overthrow the regime', but also their calling on Arab rulers to leave through the slogan 'go away.' This was done to allow the possibility of changing regimes, making them democratic in order to achieve not only social justice, but also economic growth, dignity and respect, as stated in the introduction. Interestingly, this is clearly reflected in the four studied poems, each of which end with the core issue: calling on rulers to leave their countries and give up their rules, making this departure key to the solution. The poet Matar excels in ending his poem with poetic imagery by employing the historical heritage story of Juha and the pin: 
They were not considered, but they became

It is like Juha and the pin

Go out, this is my house!

I will go out only with a dialogue

Leave! this is my house, leave!!

I will only leave with my house!

Either follow my pin

Or to set fire to it!

al-Mūrādī also ends his poem explicitly:

"Leave!" oh people, I repeat from my home land

Leave! "this is the only solution"

I've got it! I've got it!

It is clear that the poets consider both the departure of rulers and regime change the only solution to the crisis of the Arab people and nations.

As for Msā' dih, he ends his poem by evoking a rhetorical question expressing the core hope of the Arab revolution in the Arab Spring:

Will a day come with sun shining?

The darkness commits itself

And leaves us

The great leaders and the shadows of princes?

Interestingly, the poet here refers deeply to what was not mentioned by the two former poets: wishing and hoping for the departure not only of the rulers, but also of their colleagues and assistants. That is to say, the poet talks about the comprehensive revolutionary change that Arab revolutionaries need. Indeed, revolution in his opinion requires the departure of all the holders of positions in what can be called the deep state.

Thus, we note that the four poems end with the same idea, which is characterized by the last poet-Msā' dihwith depth and comprehensiveness. However, each poet expresses the mentioned motive using clearly different poetic methodological approaches. While Matar presented the notion by a historical narrative employing Arab ancient heritageI will return later to this in analytical detail - the poet Msā'dih employed a rhetorical question to express the hope of achieving the desired change through the departure of Arab rulers. Further, the poet al-Mūrādī used simple words directly, relying on the actions adopted by the revolutionaries in their central slogan mentioned in the introduction. Note that these poems not only commemorate the mentioned Arab revolutions, but also document poetically historical details regarding their aims and agenda. In this context, Einbinder (2002) says: "Commemorating events that are often otherwise inadequately documented, these poems [some Jewish poems] have been mined for historical information" (p. 386). This strengthens the idea that poetry or fiction in general can contribute significantly to documenting historical events. Einbinder explores that in recent years, researchers and historians have begun to use them as documentary sources written in "lyrical and allusive language." However, careful reading of such poetic texts reveals significant historical points and details, which makes them critical for historical accounts. Furthermore, these poetic texts reflect to what extent poets are committed to national issues and agendas. In this context, the four studied poems seem to construct the Arabic social national conception and attitude towards Arab dictator regimes and rulers. Gluzman (2012) confirms that poetry reflects social political collective attitudes; he says: "The poetry of the statehood generation has been understood as expressing an ideological rejection of the collectivist values both of the Palmah generation..." (p.172).

As for Obaydī, he ends his poem with poetic wisdom, which means that when the people revolt against dictatorial rulers and regimes, it is certain that the ruler will step down and leave his country. He says:

If people ever want life, fate must respond

Darkness must dissipate and shackles must be shattered.

I will return to discuss this poetic wisdom method employed by Obaydī. Regarding poetic diction, we find that the poet Matar uses some words to make fun of Arab rulers, especially whom their nations revolted against them, calling them all evil. The poet also describes the former Libyan ruler Muammar Gaddafi as a madman and as like a mouse- - a reference to his weakness and lack of grace in front of the rebels who took him on the streets killed him.

Furthermore, Matar employs powerful words to be appropriate to the context of revolution and rebellion, and to be consistent with the spirit of revolution and the desire for change. Here are several examples: revolutionaries, destruction, hurricane, volcano, threatened, killed, nail, fire. There is no doubt that the poet fits his diction into the context to make the poem relevant. In addition, the poet employs words that show class differences and points out differences in the economic capabilities of the classes of Arab societies. Here are several words that refer to the poor class: thirsty, hungry, poor, misery. 
Other words refer to the class of rulers and their servants: meat with hot bread, pottery vessels, cities and palaces, gardens with rivers, wealth. Through this variation in the meaning of words, the poet highlights class differences in Arab societies, thus indicating large differences and deep socio-economic gaps that confirm the injustice of these poor classes. In this context, the poet refers to and employs his poetry to document the historical fact that Arab rulers become very rich early in their rules, a clear sign of corruption in Arab regimes. Matar compares the socio-economic statuses of Arab rulers before and after taking power:

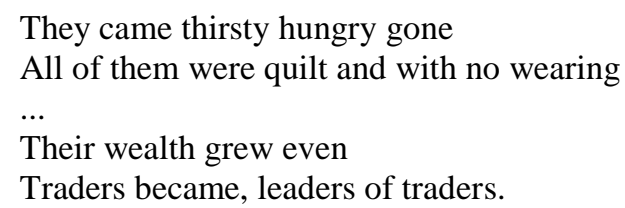

Al-Mūrādī is characterized by his poetic diction, which highlights words and expressions of great importance because they reflect the causes and major motives of the revolution. It is true that the poet talks specifically about the revolution in Yemen, but, as mentioned earlier in the introduction, these reasons and motives are similar or identical in all the Arab countries that rose against their rulers and regimes. Some of these words and expressions reflect the reasons behind the revolution: humiliation, worries, massacres, atrocities, slavery and serfdom (absence of freedom), the government is killing its own people.

Msā' dih's poetic diction is partly similar to Matar's, since it includes traditional words such as: horses, stagnation, spear, desert sand, magic, and fish-hook. It also contains some words of power such as rebelling, blood, spear, unbowed, chivalry, martyrs, and erupt.

In terms of content, not only is Msā dih's poem characterized by poetic narration and perpetuating the wishes of the Arab revolutions, goals, and motives, but it also calls for continuing and straightening the course of such revolutions by saying:

Is there a day when our bodies rise?

to swim against the current

and we sense the feeling of upright, unbowed

Is there a day when the martyrs forgive us?

When our chivalry was trembling in a condolence house.

As regards the poetic methods, Matar's poem includes a considerable variety of poetic styles employed for semantics and historical literary documentary. Matar surprises his readers, because while they expect to face imagination and deviation from reality and truth in poetry, the poet employs a narrative style to present the major story of the Arab rulers in the Arab Spring: Ben Ali, Gaddafi, Mubarak, Bashshar, Ali bin Saleh, and others. Besides this major story, there is another traditional story, Juha and the pin, to remind readers of past Arab glories and legacy. There is no doubt that the narrative style is exciting and attractive to poetry readers, as it makes the poetic text more realistic, which is consistent with the documentation and historical narrative of the Arab Spring revolutions. It also confirms that the poet lived the reality faced by his people and society and feels and expresses it. Matar is committed to employing his poetry to stir the pain of his people and their hopes, believing in the goals of the revolutions and endeavors. His use of narrative fits with historical writing or documenting. Matar employs the historical narrative by employing poetic chronicle: the first, second, third, fourth, fifth, and so on. This serial arrangement of the Arab revolutions and events shows the poet's great interest in history. This approach may agree with poetry reader's awareness of the sequence of historical events. They can confirm that these successive Arab revolutions affected each other, as I mentioned in the introduction. All this confirms the success of the poet in his adoption of the narrative style of poetic chronicle. Thus, Matar contributes by creating a continuous historical narrative with commentary and ironical poetry. About a similar context, Einbinder (2002) says:

Remarkably, Schirmann fashioned a continuous narrative on the basis of thirty-four verses of penitential poetry. In this particular instance, the events he sought to reconstruct were not unfamiliar: three medieval Hebrew prose chronicles recount the gruesome massacres... (p. 387)

In addition, Matar adopts the method of religious contextuality, which also gives the text realism and vitality because the religious text is common and clear in the consciousness and collective memory of Arab poetry readers. The emergence of the religious text in the poem gives it objectivity and credibility for the readers. It also confirms the significance of what the poet narrates and the historical facts and events he presents through a poetic chronicle. 
These include: verses, foresight, heaven, fire.

Prodigies for people with insights

Is he in heaven or in the fire

The poet also employs the method of poetic recycling. He begins and ends his poem with the same lines or the same issue or idea:

The beginning line of the poem is: "I have a puzzle, rebels"

The last two line of the poem are:

This is my puzzle, it is now understood?!

Who did not understand it is...!!

There is no doubt that the beginning of this poem is exciting, as it draws the attention of the poetry readers, pushing them to continue reading to identify what the puzzle is and discover its solution. In the end, he confirms that his poem has clarified the puzzle and made it understandable and clear to the readers. The method of recycling may be intended to alert the readers and focus their attention. Undoubtedly this method highlights the most important issue and the key theme in the poem.

Matar depends on the method of poetic semantic exaggeration by words of special structure, such as: 'Makkār' (very smart), 'Bashshār' (a person who gives many promises), 'sabbāk' (plumber), and 'thuwwār' (revolutionaries). This means that the poet opted for words with effective semantic exaggeration. This method makes the poetic text more powerful and achieves amplification of the attributes indicated and confirms their role and relevance to the poetry readers.

In addition, Matar uses the poetic rhetorical questioning method in both its affirmative and disapproving types. This is to avoid directness, and to diversify methods in order not to bore the reader. Moreover, it calls the reader to think and determine the idea of the poet. That is to say, the poet shares ideas and contents with the reader, therefore promoting, interacting with, and taking the reader into account.

For example, Matar says:

When the owner says: Go

you are a usurper. Is it fault or disgrace!?

This is a disapproving rhetorical question, in which the poet denies that the revolution calling for the ruler to leave is a disgrace, fault, deficiency, or bad manners. Here, the poet raises a rhetorical question in the surface structure, but he pushes the readers to bring themselves to the desired deep structure. The poet also uses affirmative questioning:

Is my puzzle understandable?!

Who does not understand it!!!

The deep structure, here, is clearly a puzzle that is now comprehensible, clear, and unequivocal. Readers are required to reach that deep structure themselves. This requires an active rather than passive reader.

Not only does Matar use these various poetic methods and styles, but he adds to the method of poetic dialogue/discussion between the ruler and protestors. There is no doubt that the dialogue/discussion method increases reality, credibility, and objectivity, since the discussion provides room for multiple voices in the text:

They said: You are worthier of your house

The family is the worthier of the house...

I have treated you well, but you are ungrateful

They replied: Hush you are garrulous.

Regarding reality and its significance for poets, Mayhem (2009) assures: “In twentieth-century literature, 'realism' tends to be preferred vehicle for the imposition of a particular ideologically correct vision of reality" (p. 52).

Thus, in comparison with Msā' dih and al-Mūrādī, the significant variation of poetic methods in the examined poem of Matar increases its poetics, distinctiveness, and artistic level. Perhaps this is due to the experience of Matar and to his decades-long career with poetry before the Arab Spring revolutions. In this context, it is worth noting that historians are influenced by the poetic and rhetorical methods employed by poets (Gluzman, 2012). However, not only are historians influenced by the poetic and rhetorical methods of poets, but readers are too, especially because in the studied poems, the poets are interested in communicating with the Arab public in order to expand their national social political consciousness.

Al-Mūrādī's poem is characterized by poetic addressing and calling styles. This is shown by the prevalence of the imperative form throughout the poem. The poet says:

Augur well oh remnants of protestors

And bode ill you symbol of thugs 
Furthermore, the poetic method involves addressing and calling through the popular vocative tool $(\mathrm{Oh})$ :

Oh wicked, the masters of scandals

Oh, bastards and villains of massacres and atrocities

There is no doubt that the poetic method of addressing and calling makes the text dynamic and realistic.

To be consistent with the poetic addressing and calling, the poet uses the method of the poetic disapproving question, rather than the affirmative one. Al-Mūrādī says: "Has your revolution been fruitful?" and "What is new?" These indicate that the Arab Spring revolution in Yemen has achieved nothing new, and that the Yemeni people have not yet reaped any good from it. Hence, pessimism is common in the poem and dominates its atmosphere. In addition to his idea that the revolution in Yemen did not renew anything, Al-Mūrādī refers to the political, cohort, religious, or sectarian polarization regarding leaders. He says:

Jelly, weak leaders

order sheikhs and do as they request

The poet therefore sees that the revolution in Yemen did not achieve its desired goals. He focuses on failure and relapse. Although the poet does not provide a clear historical narrative of the revolution and its events, he refers to the massacres and atrocities caused by the leaders and rulers of Yemen. He says: "Oh, bastards and villains of massacres and atrocities." This is a clear reference and a poetic documentation worthy of the Yemeni people and the tragedies brought by the rulers and their auxiliaries. Therefore, like Matar, he describes the rulers of Yemen as "ashrār" which is the plural of evil. Not only does he do that, but he also refers to the administrative and financial corruption inflicted by these rulers by calling them: "masters of scandals." Note that the poet does not stop at his attack against the rulers, he also criticizes the rebels in Yemen, as he sees that they seek cohort or personal interests. In saying "Oh, rebels are slaves of interests," he asserts as mentioned earlier that the revolution did not yield any good. He also criticizes the rebels and leaders because of the failure of their revolution. "Has your revolution been fruitful?" He mocks the revolution, the rebels, and the leaders for their failure and relapse.

Al-Mūrādī is characterized by the use of colloquial language, which is shown, for example, in saying:

Leave, you people from my land, I repeat (repeat here is used in colloquial Arabic)

From this to vein to this vein and (this vein is colloquial and means this artery)

He also does this in other words, like rebel, rebels, thugs, and others. The purpose of using colloquial language may be to add reality to the poetic text and to be close to the reader's awareness and language. However, we should not forget that this could reduce his readership, as colloquialisms are not unified in the Arab world. Nonetheless, standard Arabic is unified and understood by all Arabs and those who speak Arabic language.

Al-Mūrādī is similar to Matar in using the poetic recycling method. He reiterates the beginning of his poem at the end:

Again
Corruption and the rebel always increase
ahead of the world with my voice shouting

With minor additions at the end, he adds the issue of calling the ruler to leave, as mentioned above.

In contrast to the pessimism in al-Mūrādī's poem, there is optimism in Msā 'dih's poem, which is dominated by rhetorical affirmative questions. Through these rhetorical affirmative questions, the poet expresses the hopes and wishes of the Arab peoples who revolted during the revolutions of the Arab Spring 2010-2011. This poetic method is repeated thirteen times in the poem. Every time, there is an expression of a different wish or hope: the wishes and hopes of the Arab societies, especially against their rulers in the Arab Spring in Tunisia, Egypt, Libya, Yemen, and Syria. The poet hopes that Arabs will awaken from their defeat and get rid of their enemies, as well as becoming fearless of rulers, victimizers, colonists, and occupiers. He also hopes that oil will rebel against the rulers in the sense that Arabs should not rely on oil alone in the economy. He says:

Is there ever a day when oil is rebelling against us?

and tells all land brokers

enough... enough with stupidity

There is also a wish that expresses the pursuit of dignity and living in dignity and respect. This wish is for the Arab blood to become expensive, which refers to the prevalence of injustice, murder, and the contempt of Arab rulers regarding the blood of Arab peoples. The wish that is most closely associated with the objectives of the Arab revolutions in the Arab Spring is in Msā dih's poetic rhetorical question: 


\author{
Is there a day \\ when the sun shines \\ and darkness disappears \\ and leave us the powerful, and shadows of leaders and princes?
}

This means that the poet wishes for the wishes of the Arab Spring revolutions: freedom, dignity, and the end of tyranny and oppressive dictatorial regimes. Not only does he wish for the resignation of the rulers, but also for their auxiliaries and accomplices. This means changing all employees and officials of the deep state until the objectives of the revolutions are achieved. This would ensure that there will not be counter-insurgency against the revolution and its objectives.

This last wish brings us to the style of poetic symbolism used by Msā dih in his poem, which is characteristic of the poet. The sun is a symbol of freedom and darkness is a symbol of tyranny and injustice. This style also appears in other places in the poem, such as:

\title{
When colors change and all names
}

Here, the colors and names symbolize all the positions and tools of government. The poet expresses the desire of the revolutions to bring about a full change, not only in changing the name of the prime minister or the head of state, but rather in changing all positions and influential positions in the state. This means a fundamental change in governance regulations, making them democratic, affecting the heads of state, governments, members of governments, constitutions, and systems to in turn affect the destiny and quality of peoples' lives.

The style of poetic symbolism also appears in the saying:

Is there a day when the Arabian Sea changes?

and the bottom erupts

Perhaps this is a reference to the geographical dimension of the Arab world and the wish of the Arab revolutionaries that these boundaries disappear among the Arab countries to cooperate and participate in the construction of prosperity and economic and social growth.

About symbolism, Kellert (2012) says:

Above all else, what makes humans distinctive is our use of symbols to represent reality. Indeed, our lives are largely lived via symbols, which provide the basis for our language, speech, and ability to communicate, as well as our capacity to imagine, create, and form culture. While literalists view symbols as somehow less than real, these representations of reality are among the most defining characteristics of our species, and a critical dimension of the human mind. (108)

That is to say, the poet Msā dih takes the target audience in account, motivating readers to imagine and contribute to forming a culture based on democracy and freedom, as well as social and economic justice.

It is obvious that neither al-Mūrādī nor Msā 'dih use historical narrative in their poems. Msā' dih merely documents the goals and aspirations of the Arab revolutions. This poetic documentation of the Arab revolutions' objectives in the Arab Spring of 2010-2011 is in itself a historical work because it celebrates those revolutions and their lofty and humane goals of justice, equality, democracy, etc.

Thus, we note that Matar surpasses al-Mūrādī and Msā 'dih, not only in poetics and the significant diversity of poetic methods, but also in the historical narrative and the harmony of poetic methods. Matar employs them for the historical poetic documentary narrative of the Arab revolutions that occurred at the end of the first decade of the twentyfirst century (2010-2011).

One of the poetic methods used by both al-Mūrādī and Msā dih, but not by Matar, is repetition. Al-Mūrādī repeats the phrase "nothing new" five times, because this phrase forms the focus of the poem. However, the poet seems to attempt to highlight a different issue every time he says "nothing new." Moreover, by using "nothing new," the poet assures that there is "nothing new" even though the rebels have accomplished many steps in their revolution. Thus, the method of repetition aims at highlighting and consolidating the idea of the poet in the reader's mind and consciousness. The poet repeats the word "Oh" too, because he adopted the poetic method of calling and addressing in his poem. Al-Mūrādī repeats "Oh" to be able to address all sides involved in the revolution, such as rebels, rulers, leaders, and the general public. Not only that, but he repeats the imperative verb "Get out" twice at the end of the poem: 
"Leave!" oh people, I repeat from my home land

"Leave!" this is the only solution

This act significantly reflects a great goal of the Yemeni revolution, as well as other Arab revolutions in the Arab Spring. That goal is that Arab rulers should step down from their positions in order for the rebels to change the regime into a democratic one.

Msa'deh repeats "Will the Arab spring...?" three times in the above-mentioned poem. Moreover, he repeats the poetic rhetorical interrogative sentence - through which he expresses a wish or goal as mentioned above--"Is there a day?" five times. In all cases, the repetition allows the poet to reflect the wishes of the revolution and the Arab rebels in the Arab spring, as well as the goals of the revolution. This is consistent with what I mentioned earlier regarding the content of the poem. The repetition in his poem aims to highlight the wishes of rebels and the goals of their Arab revolutions; furthermore, it makes them the main and central axis of the poem.

I presented the three free verse poems above not only because they reflect the Arab revolutions, but also because of their poetic content and method. Next, I am going to focus on a parallel poem by Obaydī - a poem that talks in particular about the Egyptian revolution in the Arab Spring. In the course of examining this poem, I will strive to analyze the image of the Egyptian revolution in the Arab Spring (2011) in addition to studying the poetic methods and language and how to use them to clarify and explain that image.

It is clear that Obaydī’s poem reflects and narrates the revolution of the Egyptian people in the Arab Spring against President Hosni Mubarak and his tyrannical regime. The poet says:

Egypt, too, shouted loudly and people erupted from a deep sleep

Egypt, too, revolted and the fire bursts into flames.

The following are reflected in the poem above: The motives and goals of the revolution, the economic cause and the pursuit of economic growth to eliminate unemployment, poverty and deprivation, and the pursuit of freedom and living with dignity and respect. The poet says:

The voices of the people in the homelands are high and became complaining to God

We want human dignity, to live free lives as men

We are fed up with misery and deprivation; we are fed up with humiliation and corruption

The people's determination to bring about change is also reflected. The fear of the ruler no longer exists and the rule of iron and fire is no longer useful to the ruler in front of the millions who went out to demonstrate and sit in Tahrir square in the heart of Cairo, the Egyptian capital. The Egyptians insisted to demonstrate and sit in without fear, willing to die in order to gain freedom and dignity and eliminate tyranny, injustice, oppression, deprivation, and poverty. Obaydī says:

We see determination and great insistence, insistence causing trembling mounts

We see the free die and do not care, the era of living in shackles has come to an end

Here comes generous freedom, blood-filled daggers, and blades. It also reflects the success of the revolution and the stepping down of the ruler and his departure from Cairo to Sharm el-Sheikh:

I saw the tyrant as he demonstrates, rays of truth fade away

The loud voice of the people heard across the land, tyrants of evil withdraw

In his poem, the poet Obaydī asserts that freedom is precious, so the Egyptian people are prepared to sacrifice their lives for it. Therefore, they do not fear death or murder in their insistence on freedom and living in dignity. Living with dignity refers to and reflects the degree of suffering Egyptian people have been through during the tyranny of rulers. They faced injustice and humiliation in various forms such as arrest, imprisonment, and torture without trial. Tyranny is reflected in other economic images as well, such as widening gaps between socioeconomic classes in Egyptian society. There is no doubt that the rate of poverty and unemployment was great under the rule of Mohamed Hosni Mubarak, which lasted more than 30 years. The freedom sought by the Arab revolution in Egypt reflects the desire of Egyptians to obtain all kinds of freedoms, such as freedom of speech, work and property, movement and travel, political participation and political organization, and the establishment of charitable and humanitarian associations.

The poet expresses all of this in various, worthy linguistic and poetic methods characterized by poetic and verbal music. Among these methods is poetic imagery. Obaydī assimilates young rebel and protester Egyptians as strong, eager lions fighting without fear of death or imprisonment against an erratic, corrupt oppressor. The poet is creative when describing them as lions that God has kept for the last moment - the moment of furious revolution in Egypt.

Obaydī also uses diversified conditional sentences in his poetic imagery. This is apparent in the penultimate and antepenultimate verses of the above-mentioned poem. He considers the ruler to be an oppressor-the poet is the truth and 
the light emitting hope and lighting the way of rebels. Moreover, when the people revolt shouting, the people will defeat the unjust ruler no matter how powerful he is.

The last two lines of verse can be considered wisdom provided by the poet to the reader - a wisdom similar in content and method to what Abu al-Qasim al-Shabi said:

If people ever want life, fate must respond

Darkness must dissipate and shackles must be shattered.

Thus, Obaydī ends his poem with that wisdom. This is a worthy style. In all the previous verses, he only spoke about the Egyptian revolution. In the last two lines, however, he moves to general discourse about revolutions, as if he is inviting other Arab peoples to revolt and encouraging them by confirming the desired result, which is the stepping down of the ruler and changing the regimes into democratic ones, thus achieving the revolution's goal and the wishes of the rebels. Note that employing wisdom throughout poetry makes the poetic text both subjective and universal. In this context, Cook (1991) says: "There is a wisdom in the best poetry that makes it universal, rather than just subjective, though such wisdom derives from the engagement of subjectivity" (p. 317). Furthermore, Cook (1993) explores the relationship between wisdom in poetry and contribution to human ethics and behaviour:

The finality of a poem, and its mounting of modalities, aims its wisdom at a vision of human behaviour, and so, implicitly, at ethics. The reader of a story in a novel, too, or the viewer of one on stage wishes to include the story in some pattern of plausibility and rightness, a system of what is ultimately justice, as well as to be moved into a heightened feeling, to share as well as to understand the states that literature envisages. (p. 136)

In this context, it is worth noting that Obaydī's wisdom contributes to human ethics by calling and encouraging Arab people to revolt against dictatorial regimes and rulers because such behaviour will bring freedom, democracy, and socio-economic justice.

The poet also uses comparison and contrast between the past and the present, which could be considered historical poetic documenting: the past has been dominated by a life of humiliation, deprivation, tyranny; a revolting present insists on gaining freedom, dignity, and eliminating tyranny and injustice. This is also apparent in several other places in the poem that observe the past and document it, for example:

We are fed up with misery and deprivation,

We are fed up with humiliation and corruption.

Among the lines that document the present — the present of the Egyptian revolution in the Arab Spring of 2011—is:

We want human dignity, to live free lives as men

We see the free dies and does not care,

the era of living in shackles has come to an end

The purpose of the above comparison, between the past and present, is to highlight and intensify the change that has taken place in the Egyptian people, namely, their insistence on liberation and the revolution against injustice, deprivation, poverty, and political, economic, and social tyranny. This comparison also perpetuates the reasons and motives of the Egyptian revolution and the goals it wished to achieve.

In this context, Obaydī is creative, as he documents the revolution using semantic exaggeration. He describes all Egypt, not merely Egypt the civilization of past glories. All of Egypt revolted against the ruler and his regime:

Egypt, too, shouted loudly and people erupted from a deep sleep

Egypt, too, revolted and the fire bursts into flames

Using that, the poet wanted to devote his narration and historical poetic documentation of the Egyptian revolution, which took its finest form in the sit-ins of Tahrir Square in Cairo 2011. The place is of great importance when documenting the historical event, so the poet was able, through these various poetic styles, to document and perpetuate the Egyptian revolution's causes, goals, success, and results. There is no doubt that this is a historical document of the Arab Spring, especially since the Egyptian revolution played a significant role, as mentioned earlier, in encouraging other Arab peoples to revolt against tyrannical rulers and corrupt regimes.

Additionally, the poetic diction is consistent with the diversity of poetic methods. We note that the diction includes words that demonstrate the goals of the revolution on the one hand and words which list the causes of the revolution on the other. Some of the words that refer to the goals of the revolution include: free life, human dignity, freedom, the ray of truth. Words that refer to the causes of the revolution include: misery, deprivation, humiliation, corruption, tyranny, shackles. 
The poem is also rich in poetic powerful words such as: erupted, revolted, fire, determination, great insistence, trembling mountains, daggers, blood, the free die and do not care, lions, the loud voice of the people. This is similar to Matar's poetic diction examined above.

There are many linguistic errors and grammatical mistakes in al-Mūrādī’s poem, for example: The noun 'adawāt' [tools] is mostly considered as a feminine sound plural, so it could not be with a-nunation. As accusative it must be with short vowel/I or i-nunation. If 'adawāt' is considered a broken plural, then it could not be with any nunation, and as accusative it should be with the short vowel /a. Thus, 'adawātan' (with a-nunation) as used by the poet al-Mūrādī is a grammatical error.

Another grammar error is in the noun 'khayr' [good or welfare], which should be accusative with a-nunation as a direct object of the preceding verb 'janaynā' [we got or achieved]. A linguistic error is in the use of the preposition 'min' that should be replaced with the preposition 'bi' because 'bi' is used with the term 'dāqa thar' an' [tired], not 'min' as it was used in the Quran: (Hud, 77)

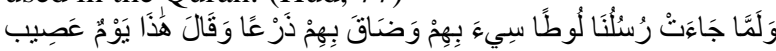

$$
\begin{aligned}
& \text { سورة هود } 77 .
\end{aligned}
$$

In Msā'dih's poem, however, only one grammatical mistake was found. Nonetheless, it was repeated seven times. The grammar error is 'yawman' [one day], which is not an adverb of time in these sentences, so it must be nominative not accusative, because it is the actor of the preceding present simple verb which is ' $y a$ 't $\mathbf{1}$ ' [come].

The poems of Matar and Obaydī are free of grammatical mistakes and linguistic errors. This indicates the apparent disparity in culture and linguistic knowledge among the four poets whose poems are examined in this study.

\section{CONCLUSION}

Undoubtedly, the Arab Spring revolutions (2010-2011) played a significant role in changing the course of history in the Middle East, causing prolonged intensive civil and non-civil armed conflicts. The Arab Spring revolutions (2010-2011) aimed to change Arab dictatorial regimes in order to bring freedom and democracy, socio-economic justice and dignity, employment and economic development, and growth. All of these aims and motivations are clearly reflected throughout modern Arabic poems. Modern Arabic poetry contributes considerably to historical writing and documenting, as well immortalizing not only the Arab Spring revolutions (2010-2011), but also the motivations, aims, and impacts of these revolutions. Interestingly, the studied poems show that poetry can contribute to poetic documenting and immortalizing historical events through various intensive poetic and artistic methods and styles. In this context, this study has shown that the poets Matar and Obaydī are noteworthy not only for their diverse poetic rhetoric and imaginative poems, but also for their considerable historical documenting.

\section{REFERENCES}

- Acemoglu, Daron and Suresh Naidu, and others (19, May, 2014). Democracy causes economic development? http://voxeu.org/article/democracy-and-growth-new-evidence.

- Ba'albakī, Laylá (2009). The Disfigured God. Beirut.

- Baum, Matthew and David Lake (2003). The Political Economy of Growth: Democracy and Human Capital, American Journal of Political Science, Vol. 47, No. 2, pp. 333-347.

- Cook, Albert (1991). The Canon of Poetry and Wisdom of Poetry, The Journal of Aesthetics and Art criticism, 49:4, pp. 317-329.

- Cook, Albert (1993). Canon and Wisdoms, Philadelphia: University of Pennsylvania Press.

- Cook, Guy (2000). Language Play, Language Learning. Oxford: Oxford University Press.

- Doucouliagos, Hristos And Mehmet Ulubasogla (2008). Democracy and Economic Growth: A Meta-Analysis, American Journal of Politics Science, Vol. 52, No. 1, pp. 61-83. http://www.jstor.org/stable/25193797

- $\quad$ Einbinder, Susan (Fall 2004). Review Poetry and History Beautiful Death: Jewish Poetry and Martyrdom in Medieval France. Princeton and Oxford: Princeton University Press. Prooftexts, Vol. 24, No. 3, pp. 386-400. http://www.jstor.org/stable/10.2979/pft.2004.24.3.386

- $\quad$ Ewenstien, Paul (2012). The Arab Spring and the Revolutions of 1848 www.academia.edu/1851294/The_Arab_Spring_and_the_Revolutions_of_1848?auto=download

- Ghanem, Hafez (2016). The Arab Spring Five Years Later: Toward Great Inclusiveness, Brooking Institution Press. http://www.jstor.org/stable/10.7864/j.ctt1657tv8.5

- Gluzman, Michael (2012). Sovereignty and Melancholia: Israeli Poetry after 1948, Jewish Social Studies, Vol. 18, No. 3, pp. 164-179.

- Harel-Shalev, Ayelet and Shir Daphna-Tekoah (2016). Bringing Women's Voices Back In: Conducting Narrative Analysis In IR, International Studies Review, Vol. 18, No. 2, pp. 171-194. 
- Henry, clement and Jang Ji-Hyang (editors) (2013). The Arab Spring: Will It Lead to Democratic Transitions, New York: Palgrave Macmillan.

- Igbaria, Khaled (2018). Homogeneity within Laylá Ba'albakî’s short stories, People: International Journal of Social Sciences, 3(3), 1637-1656.

- Kellert, Stephen (2012). Birthright: People and Nature in the Modern World. New Haven, London: Yale University Press.

- Lake, David and Matthew Baum (2001). The Invisible Hand of Democracy: Political Control and the Provision of Public Services, Comparative Political Studies, Vol. 34, N. 6, pp. 587-621.

- Lanchovichina, Elena (2018). Eruptions of Popular Anger: The Economics of the Arab Spring and its Aftermath, Washington, DC: The World Bank.

- Makdisi, Samir (2017). Reflections on the Arab Uprising, In Giacomo Luciani (Editor) Combining Economic and Political Development: The Experience of MENA, Brill.

- Matar, Ahmed (2012). An al-thawrāt al-rabī' al-'arabī [On the Arab Revolutions]. Sout algnoub: http://www.soutalgnoub.com/vb2/showthread.php?t=48638 (July 2018).

- Mayhem, Jonathan (2009). The Twilight of the Avant-Garde: Spanish Poetry 1980-2000, Liverpool University Press: Liverpool.

- Msā' dih, Ahmad (2013). Qasīdat ...Al-rabī' al- 'arabī [The Poem on The Arab Spring]. Arab Times Blogs: http://www.arabtimes.com/portal/article display.cfm?ArticleID=32051 (July 2018).

- al-Mūrādī, Mus'ab (2012). Lā jadīd [Nothing New]. Nogoom Masrya: https://www.nmisr.com/vb/showthread.php?t=432813 (July 2018).

- Obaydī, Ibrāhīm (2012). Surākh al-sha'b [Shouting of the nation]. Nogoom Masrya: https://www.nmisr.com/vb/showthread.php?t=432813 (July 2018).

- Rodrik, Dany (2003). Globalization, social Conflict and Economic Growth, The World Economy, Vol. 21, No.2, pp. 143-158.

- Salahuddin Mohd, Shamsuddin and Sara Hj. Ahmad (2017). Authenticity of classical Arabic and its relation to Aristotelian Logic (In the opinion of some orientalists and Arab scholars), World Journal of Education, Vol. 7, No. 4.

http://wje.scieedupress.com

- Simon, G0erge (2015). Poetry and The Arab Spring, CUNY Academic Works. http://academicworks.cuny.edu/gc etds/624.

- Singh, Subhash (2012). The Arab Spring: A Revolutionary Wave for Human Rights, Doctoral Research, School of International Studies, JUN, New Delhi, Samaj Vigyan Shodh Patrika, Vol. 1, No. XVIII, pp. 204-212.

- Tanenbaum, Adena (2002). Poetry and History Beautiful Death: Jewish Poetry and Martyrdom in Medieval France. Princeton and Oxford: Princeton University Press.

- Tete, Ashish and Dash, Kanta. Understanding the Arab Spring: Examining Civil Resistance Theory, School of International Studies, Ravenshaw University. http://www.academia.edu/6445168/understanding_the_Arab_Spring?auto=download 